\title{
Advances in yeast autolysis technology - a faster and safer new bioprocess
}

\section{Avanços na tecnologia de autólise de levedura - um novo bioprocesso mais rápido e seguro}

\author{
Edson Marcelino Alves ${ }^{1 *}$ (D), Joyce Faria de Souza1 ${ }^{1}$, Pedro de Oliva Neto ${ }^{1}$ \\ ${ }^{1}$ Universidade do Estado de São Paulo (UNESP/Assis), Instituto de Pesquisa em Bioenergia (IPBEN), Laboratório \\ Associado - Assis, Assis/SP - Brasil \\ ${ }^{*}$ Corresponding author: Edson Marcelino Alves, Universidade do Estado de São Paulo (UNESP/Assis), Instituto \\ de Pesquisa em Bioenergia (IPBEN), Laboratório Associado - Assis, Av. Dom Antônio, 2100, CEP: 19806-900, \\ Assis/SP - Brasil, e-mail: edsonmaralves@hotmail.com
}

Cite as: Alves, E. M., Souza, J. F., \& Oliva Neto, P. (2021). Advances in yeast autolysis technology - a faster and safer new bioprocess. Brazilian Journal of Food Technology, 21, e2020249. https://doi.org/10.1590/19816723.24920

\begin{abstract}
The yeast autolysis process - an endogenous and irreversible lytic event, which occurs in cells caused by the action of intracellular enzymes, proteases and carbohydrases - is a well-known and an economic process, however, there is a constant risk of serious microbial contamination since there are many nutrients in the broth and this process is slow, favoring the growing of pathogens. The present work comes up with an attempt to accelerate the autolysis of Saccharomyces cerevisiae with focus on the high yield of yeast extract production through a fast, economic and simple technology. The proposed strategy is based on decreasing the $\mathrm{pH}$ of the yeast suspension at the beginning of autolysis through an acid shock to activate the cell autolytic system under stressful conditions of temperature and $\mathrm{pH}$. The influence of cell concentration, temperature, time and acid shock at the beginning of the autolysis on yeast extract yields were studied. The best yields of proteins and total solids were observed for autolysis treated with acid shock $\left(\mathrm{H}_{2} \mathrm{SO}_{4} 10 \mu \mathrm{L} / \mathrm{g}\right.$ of dried yeast and final $\left.\mathrm{pH} 4.4\right)$ at $60{ }^{\circ} \mathrm{C}(36,84 \%$ of protein and $48,47 \%$ of total solids extracted) and gradual increase of temperature 45 to $60{ }^{\circ} \mathrm{C}(41.20 \%$ of protein and $58.48 \%$ of total solids extracted). The shock could increase the speed of the process since the control reached about $30 \%$ of extract at $60{ }^{\circ} \mathrm{C}$ and the same experiment, however, with acid shock reached more than $43 \%$ in $12 \mathrm{~h}$. When considering time in an industrial scale, it could be noted that the time was very important for the productivity as well as avoiding risk of pathogen contamination in autolysis. These results were very relevant for industrial purposes in the production of yeast extract, autolyzed yeast and glucan and mannan.
\end{abstract}

Keywords: Autolysis; Acid shock; Yeast extract; Protein extraction; Saccharomyces cerevisiae; Design of experiments.

\section{Resumo}

A autólise de leveduras - um evento endógeno, lítico e irreversível, que ocorre nas células e é causado pela ação de enzimas intracelulares, proteases e carboidrases - é um processo bem conhecido e econômico. Todavia, a autólise apresenta um risco constante de grave contaminação microbiana, pois o caldo contém muitos nutrientes, além de o processo ser lento, favorecendo o crescimento de patógenos. O presente trabalho tem como objetivo 
acelerar a autólise de Saccharomyces cerevisiae, com foco no alto rendimento da produção de extrato de levedura por meio de uma tecnologia rápida, econômica e simples. A estratégia proposta tem como base a diminuição do pH da suspensão de levedura no início da autólise, por meio de um choque ácido, para ativar o sistema autolítico da célula em condições estressantes de temperatura e pH. Foi estudada a influência da concentração celular, da temperatura, do tempo e do choque ácido no início da autólise sobre o rendimento do extrato de levedura. Os melhores rendimentos de proteínas e sólidos totais foram observados para autólise tratada com choque ácido $\left(\mathrm{H}_{2} \mathrm{SO}_{4} 10 \mu \mathrm{L} / \mathrm{g}\right.$ de levedura seca e pH final 4,4) a $60^{\circ} \mathrm{C}$ (extração de $36,84 \%$ de proteína e $48,47 \%$ de sólidos totais) e aumento gradual da temperatura $45^{\circ} \mathrm{C}$ a $60{ }^{\circ} \mathrm{C}$ (extração de $41,20 \%$ de proteína e $58,48 \%$ de sólidos totais). 0 choque pôde aumentar a velocidade do processo, uma vez que o grupo controle atingiu cerca de $30 \%$ do extrato a $60{ }^{\circ} \mathrm{C}$ e o mesmo experimento, porém com choque ácido, atingiu mais de $43 \%$ em $12 \mathrm{~h}$. Visto que o tempo em escala industrial é muito importante para a produtividade e para evitar riscos de contaminação por patógenos na autólise, tais resultados foram muito relevantes para fins industriais na produção de extrato de levedura, levedura autolisada, glucanas e mananas.

Palavras-chave: Autólise; Choque ácido; Extrato de levedura; Extração de proteínas; Saccharomyces cerevisiae; Delineamento experimental.

\section{Introduction}

\subsection{Yeast extract market}

The ever-growing demand for nutritional food in the developing and developed countries has enhanced the production of yeast extracts and autolysates across the globe. As principal ingredients, they contain proteins, amino acids, nucleotides, minerals, vitamins and are used in diverse sectors of food and pharmaceutical industry (Kellershohn and Russell, 2016). Another boosting factor for yeast extracts and autolysates is associated with the increasing demand of flavor enhancers like monosodium glutamate (MSG). Studies have highlighted that yeast extract is an adequate replacement of MSG, which contributes to rising even more its market (Jo and Lee, 2008).

Basically, the global yeast market is segmented based on type (yeast extract, yeast autolysate, yeast $\beta$ - glucan, and others yeast derivatives) and application (feed, food, others). Both products, yeast autolysate and yeast extract are produced by self-digestion of yeast constituents by endo-enzymes (Šuklje et al., 2016). However, two major aspects differ yeast extract from yeast autolysate. First, yeast autolysate corresponds to the total product after breakdown of yeast cells. It contains soluble portions (amino acids, nucleic acids, salts) and insoluble components like the cell wall. Yeast extract refers just to the soluble portions after separation from the insoluble components. In addition, the autolysis step is shorter during the production of yeast autolysate compared to yeast extract (Pozo-Bayón et al., 2009). Lead by its strong application scope, yeast extract is used in several food and beverage segments, sweet or savory (Ghoush and Khatib, 2021). Snacks and prepared meals are the main food items produced using yeast extracts (Biospringer, 2021). Nowadays, with an increasing demand for ready-to-eat food items, global food industry manufacturers are committed to reducing the sodium content of their products (Musicus et al., 2020). Yeast extract stands out in this scenario because it gives good flavor and also enhances taste. Adding a certain amount of yeast extract in food and flavoring with a salt content of less than $4 \%$, could significantly improve and enhance good flavor and taste, which MSG and 5-IMP + 5'-GMP fail to do (Jo and Lee, 2008). So, the usage of yeast extract can reduce the consumers' salt intake.

Currently, yeast extracts manufacturers are concentrated in China, United States of America (USA), Europe and Japan. Some of the key players of global yeast extracts and autolysates market are Chr. Hansen A/S, Synergy (High Wycombe) Ltd., Alltech Inc., Leiber Gmbh, Angel Yeast Co. Ltd., Royal Dsm N.V., Associated British Foods Plc, Oriental Yeast Co. Ltd., Archer Daniels Midland Company, Lesaffre Group, 
and Lallemand Inc (Transparency Market Research, 2021). In addition, the market is characterized by accreditation of product, capacity expansion, capital expansion, and substantial investment decisions to improve market share of manufacturers (Biospringer, 2021). Finally, the main challenges faced by the yeast extract production sector are regarding autolysis parameters optimization for increasing profits and reducing costs. In this way, the study and understanding of the physical and chemical parameters involved during autolysis are important because the effects and interactions between them and additives may reflect positively or negatively on the expected results, as well as the chemical composition of the final product. The following section presents the main mechanisms and parameters that influence autolysis.

\subsection{Process parameters affecting yeast extract production}

The autolysis of yeasts can be understood as an endogenous and irreversible lytic event, which occurs in cells caused by the action of intracellular enzymes, proteases and carbohydrases (Podpora et al., 2015). The cell will activate this mechanism when it encounters a physiological stress. The phenomenon is characterized by a loss of permeability of the cytoplasmic membrane, altered porosity of the cell wall, decreased respiratory enzyme activity, gradual hydrolysis of the cytoplasmic material by endogenous enzymes and subsequent release of the degraded products (nutrients) in the extracellular environment (Alexandre, 2011). Small variations in physical, chemical, and biological factors like an increase in temperature, osmotic pressure, $\mathrm{pH}$, or cell starvation can significantly influence the results of autolysis (Reed and Nagodawithana, 1990). Yeast autolysates, for instance, can be obtained with different characteristics depending on the incubation temperature.

In addition to temperature, the autolytic process can be accelerated by the use of auxiliary products such as plasmolyzing agents (sodium chloride, ammonia, organic solvents, proteolytic enzymes and acids) (Malekkhahi et al., 2016). The use of ammonia, for instance, reduces process time, however, produces a dark extract. Other disadvantages of the use of additives to accelerate autolysis also include alterations in the final composition of the extract, which may present high salt concentration. Toxic compounds to animals and humans also can be formed from the use of hydrochloric acid to optimize the autolysis (Oliveira and Oliva Neto, 2011).

\subsection{Recent challenges}

Industrial autolysis process for yeast extract production can generally take from $24 \mathrm{~h}$ to a few days at relatively high temperatures (from 40 to $55^{\circ} \mathrm{C}$ ). However, contamination by microorganisms such as proteolytic and pathogenic bacteria such as Clostridium $s p$ may occur in this period (Bataeva et al., 2020). Bacteria of this genus prefer environments richer in proteins, $\mathrm{pHs}$ close to neutrality and low oxygen content, conditions found in the environment of yeast autolysis. In addition to cause diseases, these bacteria can also cause a putrid odor and dark color, which decreases the quality of the yeast extract produced.

Productivity is an important parameter when considering the production of low added-value compounds where profitability is given by the production scale. Thus, a time-consuming process becomes costlier, considering energy and labor costs. Considering these challenges, the present work comes up with an attempt to accelerate the autolysis with focus on the high yield of yeast extract production. The proposed strategy is based on decreasing the $\mathrm{pH}$ of the yeast suspension at the beginning of autolysis through an acid shock to activate the cell autolytic system under stressful conditions of temperature and $\mathrm{pH}$. In addition, this work also aimed to optimize the parameters of the autolysis process by assessing the influence of cell concentration at the beginning of autolysis and the influence of acid shock, temperature and reaction time on the extraction of proteins and solids. 


\section{Material and methods}

\subsection{Yeast biomass}

Fresh spent brewer's yeast cells of Saccharomyces cerevisiae, in the form of aqueous suspension, kindly provided by the company Cervejaria Malta (Assis-SP, Brazil) were used in this work. Usual low fermentation brewing process at temperatures between 5 and $10{ }^{\circ} \mathrm{C}$ preceded the harvesting of the cells. The methodology described by Oliveira and Oliva Neto (2011) was followed in this work in order to clean the biomass before the autolysis studies. The fresh yeast suspension was stirred for 30 min and $60 \mathrm{rpm}$ in $\mathrm{NaOH}$ solution $(0.2 \%)$ in the ratio of $1: 1(\mathrm{v} / \mathrm{v})$ for biomass debittering and then centrifuged in $1 \mathrm{~L}$ containers at $3800 \mathrm{rpm}(4794 \mathrm{x} \mathrm{G})$ for $10 \mathrm{~min}$ at $10{ }^{\circ} \mathrm{C}$ (Heraeus Cryofuge 6000 Centrifuge, Thermo Scientific, Osterode, Germany) for the removal of residues from the culture medium of the fermentative process. After washing, the cells were subjected to the autolysis studies.

\subsection{Influence of cell concentration assay}

In order to determine the best cell concentration to perform autolysis with acid shock, approximately $10 \mathrm{~g}$ of centrifuged spent brewer's yeast, having a moisture content of $75 \%$, were weighed and then added a suitable volume of water so that the autolysis was performed at percentages of yeast in water (w/v) ranging from $5 \%$ to $15 \%$, on yeast dry basis (Table 1 ).

Table 1. Parameter conditions for autolysis cell concentration influence assay.

\begin{tabular}{ccccc}
\hline $\begin{array}{c}\text { Cell concentration } \\
(\mathbf{\%})^{\mathbf{a}}\end{array}$ & $\begin{array}{c}\text { Yeast } \\
(\mathbf{g})^{\mathbf{b}}\end{array}$ & $\begin{array}{c}\text { Water } \\
(\mathbf{m L})\end{array}$ & $\begin{array}{c}\text { Control } \\
\mathbf{H}_{2} \mathbf{S O}_{\mathbf{4}} \mathbf{9 8 \%}(\boldsymbol{\mu L})\end{array}$ & $\begin{array}{c}\text { Acid treatment } \\
\mathbf{H}_{\mathbf{2}} \mathbf{S O}_{\mathbf{4}} \mathbf{9 8 \%}(\boldsymbol{\mu} \mathbf{L})\end{array}$ \\
\hline 5 & 10 & 42.5 & 0 & 25 \\
\hline 7.5 & 10 & 25.8 & 0 & 25 \\
\hline 10 & 10 & 17.5 & 0 & 25 \\
\hline 12.5 & 10 & 12.5 & 0 & 25 \\
\hline 15 & 10 & 9.1 & 0 & 25 \\
\hline
\end{tabular}

${ }^{a}$ Percentage of yeast in water (w/v), on yeast dry basis. ${ }^{b}$ Wet yeast mass after centrifugation, presenting moisture content of approximately $75 \%$.

Subsequently, $25 \mu \mathrm{L}$ of $\mathrm{H}_{2} \mathrm{SO}_{4} 98 \%$ was added and agitated. It was observed previously that the addition of $10 \mu \mathrm{L}$ sulfuric acid per gram of dry yeast was sufficient to reduce the initial $\mathrm{pH}$ of the cell suspension near to $\mathrm{pH} 2.1$, (Table 2). It was also observed previously that after approximately $40 \mathrm{~min}$ of the acid shock, the $\mathrm{pH}$ of the mixture tends to rise and stabilize. This correlation between different concentration of $\mathrm{H}_{2} \mathrm{SO}_{4}$ for acid shock and initial and final $\mathrm{pH}$ of the autolysis is presented in Table 2 .

Table 2. Correlation between different concentration of $\mathrm{H}_{2} \mathrm{SO}_{4}$ for acid shock and initial and final $\mathrm{pH}$ of the autolysis*.

\begin{tabular}{|c|c|c|c|}
\hline $\begin{array}{c}\text { Acid concentration } \\
\mathrm{H}_{2} \mathrm{SO}_{4} / \text { dried yeast }(\mu \mathrm{L} / \mathrm{g})\end{array}$ & $\begin{array}{l}\% \text { of acid in relation to dried yeast } \\
\operatorname{mass}(v / w)\end{array}$ & Initial pH & Final pH \\
\hline 0 & 0 & 5.9 & 5.9 \\
\hline 10 & 1 & 2.1 & 4.54 \\
\hline 20 & 2 & 1.9 & 2.8 \\
\hline 40 & 4 & 1.7 & 2.1 \\
\hline 1000 & 10 & 1.5 & 1.6 \\
\hline
\end{tabular}

*Autolysis with $7.5 \%$ yeast water $(\mathrm{w} / \mathrm{v})$ on yeast dry basis. 
After agitation, the cell suspension was subjected to autolysis for $60 \mathrm{~min}$ at temperature of $60{ }^{\circ} \mathrm{C}$. A duplicate of the autolysis under the same time and temperature conditions, however without addition of the acid, was performed in order to evaluate the influence of the acid treatment on the autolysis yield. After the end of autolysis, the samples were centrifuged and the supernatant was evaluated for the total protein content extracted using the classical Kjeldahl method, according to the methodology described by Association of Official Agricultural Chemists (2000), and total solids by evaporation of the yeast extract at $105{ }^{\circ} \mathrm{C}$ to constant weight according to Baird et al., (2017). Tests for protein and total solids were conducted in triplicate, and data were submitted to Analysis of Variance (ANOVA), and the means were compared by Tukey's test, using the program GraphPad Instat - Version 3.05 (Rutgers University). The treatments were analyzed statistically and considered significant at $p<0.05$.

\subsection{Influence of acid shock and temperature assay}

An I-Optimal design of experiments and response surface methodology were performed in order to optimize the parameters of temperature and acid shock (independent variables) during autolysis for maximum protein and total solids extraction (dependent variables). The modeling and statistical optimization were performed using Design-Expert software (Test version 11, StatEase Inc. Minneapolis, USA) with a 5\% significance level according to (Macedo et al., 2020). According to the I-Optimal (quartic model) design, 15 combinations including five experimental points to estimate the lack of fit and three replicates were randomly organized by Design Expert software.

For the assay, fresh cells of $S$. cerevisiae obtained from the brewing industry were subjected to the same cleaning and debittering process described in Section 2.1. Approximately $10 \mathrm{~g}$ of wet yeast (75\% moisture content) were weighed and then $25.8 \mathrm{~mL}$ of distilled water was added (autolysis with $7.5 \%$ yeast/water (w/v), on yeast dry basis). After agitation, suitable volumes of $\mathrm{H}_{2} \mathrm{SO}_{4} 98 \%$ were added so that reaction was performed at final $\mathrm{pH}$ ranging from 1.6 to 6.0 and at temperatures ranging from 50 to $100{ }^{\circ} \mathrm{C}$ according to the experimental design obtained. The thermal effect on the cells (thermolysis) at such high temperatures $\left(60^{\circ}\right.$ to $\left.100^{\circ} \mathrm{C}\right)$ inactivate the endogenous proteases and can lead to a release in protein and solids due to cell disruption. Thus, the influence of temperature and $\mathrm{pH}$ were studied in both processes, autolysis (at temperatures between $50{ }^{\circ} \mathrm{C}$ and $60{ }^{\circ} \mathrm{C}$ ) and thermolysis. After $60 \mathrm{~min}$ of reaction, the samples were centrifuged and the supernatant were evaluated for protein and total solids content as described in Section 2.2.

The best adjusted mathematical model was selected as proposed by Macedo et al. (2020), based on the comparisons of specific parameters, including the tests of statistical significance of the model, statistical significance of the parameters, as well as lack of fit test and residue analysis, with a significance level of $95 \%$. Optimization of the parameters which leads to the maximum protein and total solids extraction was obtained by using the desirability function.

\subsection{Influence of acid shock, temperature and time assay.}

In order to evaluate the influence of acid shock and temperature over the time of autolysis, approximately $50 \mathrm{~g}$ of wet yeast ( $75 \%$ of moisture content) were weighed and then added $129 \mathrm{~mL}$ of distilled water (autolysis with $7.5 \%$ yeast/water (w/v), on yeast dry basis) and an adequate volume of $\mathrm{H}_{2} \mathrm{SO}_{4} 98 \%$ was used in order to achieve the best $\mathrm{pH}$ condition obtained in the previous step. Control groups without the acid addition were also prepared. After mixing, the suspensions were subjected to the different autolysis treatments according to Table 3 for $120 \mathrm{~h}$. 
Table 3. Parameter conditions for the acid shock, temperature and time influence assay.

\begin{tabular}{cccc}
\hline Treatments & Yeast $(\mathbf{g})^{\mathbf{a}}$ & Water $(\mathbf{m L})$ & pH \\
\hline $45^{\circ} \mathrm{C}$ for $120 \mathrm{~h}$ & 50 & 129 & Control $^{\mathrm{b}}$ \\
\hline $45^{\circ} \mathrm{C}$ for $120 \mathrm{~h}$ & 50 & 129 & Acid shock $^{\mathrm{c}}$ \\
\hline $60^{\circ} \mathrm{C}$ for $120 \mathrm{~h}$ & 50 & 129 & Control $^{\mathrm{b}}$ \\
\hline $60^{\circ} \mathrm{C}$ for $120 \mathrm{~h}$ & 50 & 129 & Acid shock $^{\mathrm{c}}$ \\
\hline $45^{\circ} \mathrm{C}(0-2 \mathrm{~h}), 50^{\circ} \mathrm{C}(2-4 \mathrm{~h}), 55^{\circ} \mathrm{C}(4-8 \mathrm{~h}), 60^{\circ} \mathrm{C}(8-120 \mathrm{~h})$ & 50 & 129 & Acid shock $^{\mathrm{c}}$ \\
\hline $60^{\circ} \mathrm{C}(0-2 \mathrm{~h}), 55^{\circ} \mathrm{C}(2-4 \mathrm{~h}), 50^{\circ} \mathrm{C}(4-8 \mathrm{~h}), 65^{\circ} \mathrm{C}(8-120 \mathrm{~h})$ & 50 & 129 & Acid shock $^{\mathrm{c}}$ \\
\hline
\end{tabular}

${ }^{a}$ Wet yeast mass after centrifugation, presenting moisture content of approximately $75 \%$. ${ }^{b} \mathrm{No}$ addition of acid. ${ }^{\mathrm{c}} \mathrm{pH}$ condition selected in the previous stage of the work.

Throughout the autolysis, $10 \mathrm{~mL}$ of the samples were collected at time intervals of 2, 4, 6, 8, 12, $24,48,72,96$ and $120 \mathrm{~h}$. The samples were centrifuged and the supernatant was evaluated for protein and total solids content as described in section 2.2. Tests for protein and total solids were conducted in triplicate, and data were submitted to ANOVA, and the means were compared by Tukey's test, using the program GraphPad Instat - Version 3.05 (Rutgers University). The treatments were analyzed statistically and considered significant at $p<0.05$.

Total soluble proteins of the supernatants of autolyzed cells after $12 \mathrm{~h}$ reaction were separated using $12.5 \%$ sodium dodecyl sulfate-polyacrylamide gel electrophoresis (SDS-PAGE) under reducing condition by the method of Laemmli (Laemmli, 1970). The cell lysates were mixed with 2\% SDS with agitation for 20 min and boiled for $5 \mathrm{~min}$. The suspension was then centrifuged $(12,000 \times \mathrm{g}$ for $15 \mathrm{~min})$ and the supernatant was loaded. Protein bands were detected by Coomassie Brilliant Blue R250 staining.

\subsection{Salmonella growth assessment}

In order to assess effectiveness of autolysis with acid shock to prevent or inhibit the growth of pathogenic microorganisms, a trial with $S$. enterica subsp. enterica serovar typhimurium ATCC 14028 was used as a model of pathogenic strain (hereafter called S. typhimurium). This strain was obtained from Tropical Culture Collection (CCT), André Tosello Foundation, Campinas, SP, Brazil, with the code CCT 1478. The culture was maintained in the Laboratory of Industrial Biotechnology (UNESP-Assis / SP) at $7{ }^{\circ} \mathrm{C}$ in Nutrient Agar. Approximately $50 \mathrm{~g}$ of wet yeast $(75 \%$ moisture content) were weighed and then added $129 \mathrm{~mL}$ of distilled water (autolysis with $7.5 \%$ yeast $/$ water $(\mathrm{w} / \mathrm{v})$, on yeast dry basis). Autolysis was carried out in 2 groups as following: control autolysis (at $45^{\circ} \mathrm{C}$ and final pH 5.9 for up to $120 \mathrm{~h}$ ); and autolysis with acid shock with $\mathrm{H}_{2} \mathrm{SO}_{4} 10 \mu \mathrm{L} / \mathrm{g}$ of dried yeast (at $45^{\circ} \mathrm{C}$ and final $\mathrm{pH} 4.4$ for up to $120 \mathrm{~h}$ ). In both groups, Salmonella was inoculated at the beginning of the experiment to a final concentration of $10^{6}$ cells $/ \mathrm{mL}$. Samples were taken at regular intervals and inoculated in a petri dish containing specific medium for the growth of Salmonella (AGAR SS-530110 Laborclin, Brazil) in order to observe qualitatively the growth of the microorganism. The study was carried out only at $45^{\circ} \mathrm{C}$ because at higher temperatures, this bacterium does not survive.

\section{Results and discussion}

\subsection{Influence of cell concentration on yeast extract and protein yields}

The results of cell concentration influence on yeast extract yields are presented in Table 4 . The addition of acid at the beginning of the autolysis resulted in an increase of total solids and proteins extracted. The best result was achieved with acid treatment and $7.5 \%$ yeast/water $(\mathrm{w} / \mathrm{v})$, on yeast dry basis. Under these conditions, yeast extract presented $69.87 \%$ of proteins, which represents an increase of $12.4 \%$ in relation to the control group. On the other hand, Figures $1 \mathrm{a}, \mathrm{b}$ present the percentage of total solids and proteins extracted in relation to the initial dry mass of yeast used in the autolysis. 

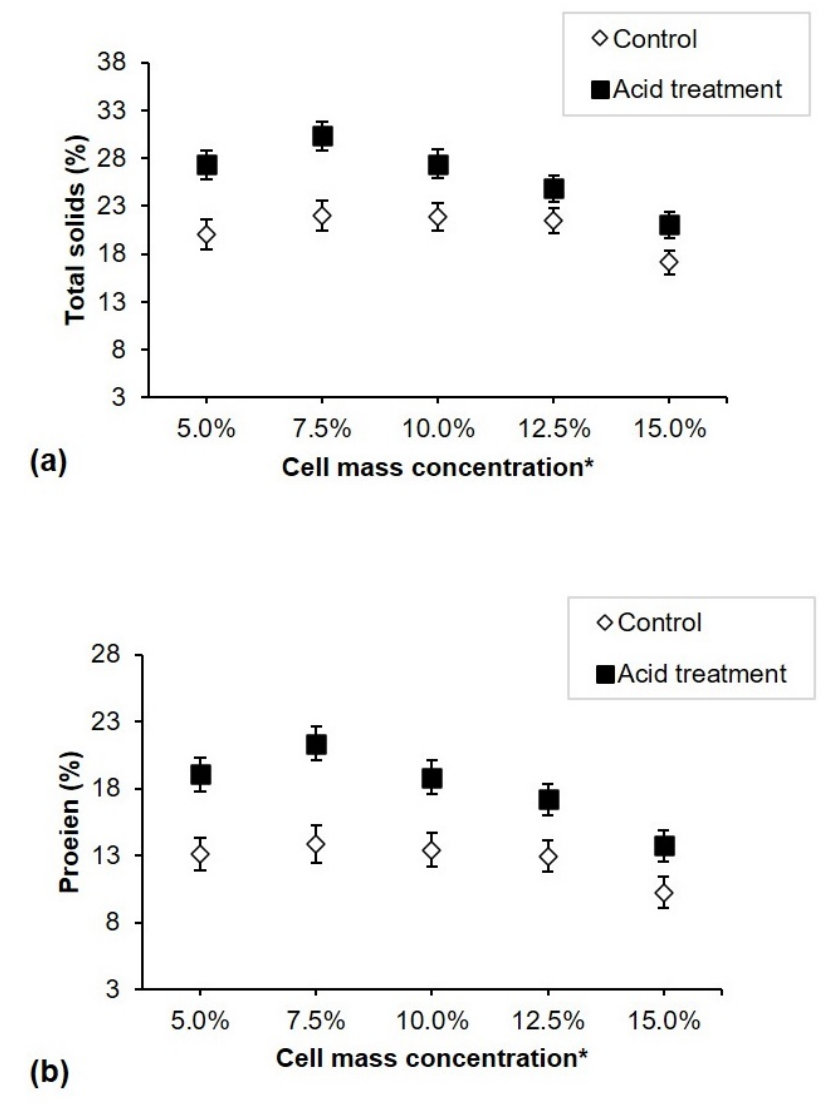

Figure 1. Total solids (a) and protein (b) content in yeast extract in relation to the initial yeast dry mass after $60 \mathrm{~min}$ of autolysis at $60{ }^{\circ} \mathrm{C}$. In the acid treatment there was an addition of $\mathrm{H}_{2} \mathrm{SO}_{4} 10 \mu \mathrm{L} / \mathrm{g}$ of dried yeast. ${ }^{*}$ Percentage of yeast in water $(\mathrm{w} / \mathrm{v})$, on yeast dry basis.

The obtained results allow to evaluate the overall efficiency of the self-digestion process. The highest yield of total solids and protein extraction were also observed with $7.5 \%$ yeast $/$ water $(\mathrm{w} / \mathrm{v})$. Under this condition, the acid treatment showed increases of $38.63 \%$ for total solids and $55.83 \%$ for protein extraction when compared to the control group.

Table 4. Total solids and proteins content in yeast extract after $60 \mathrm{~min}$ at $60^{\circ} \mathrm{C}$.

\begin{tabular}{ccccccc}
\hline \multirow{2}{*}{$\begin{array}{c}\text { Cell content } \\
(\boldsymbol{\%})^{\mathbf{a}}\end{array}$} & $\begin{array}{c}\text { Total solids } \\
(\mathbf{g})\end{array}$ & $\begin{array}{c}\text { Proteins } \\
(\mathbf{g})\end{array}$ & $\begin{array}{c}\text { Protein content in } \\
\text { the yeast extract }(\%)\end{array}$ & $\begin{array}{c}\text { Total solids } \\
(\mathbf{g})\end{array}$ & $\begin{array}{c}\text { Proteins } \\
(\mathbf{g})\end{array}$ & $\begin{array}{c}\text { Protein content in } \\
\text { the yeast extract }(\%)\end{array}$ \\
\hline 5.0 & 0.5092 & 0.3282 & 64.45 & 0.6966 & 0.4813 & 69.09 \\
\hline 7.5 & 0.5587 & 0.3473 & 62.16 & $\mathbf{0 . 7 6 9 8}$ & $\mathbf{0 . 5 3 7 9}$ & $\mathbf{6 9 . 8 7}$ \\
\hline 10.0 & 0.5543 & 0.3346 & 60.36 & 0.6906 & 0.4706 & 68.15 \\
\hline 12.5 & 0.5437 & 0.3228 & 59.38 & 0.6244 & 0.4283 & 68.60 \\
\hline 15.0 & 0.4280 & 0.2508 & 58.60 & 0.5362 & 0.3451 & 64.36 \\
\hline
\end{tabular}

a Percentage of yeast in water (w/v), on yeast dry basis. ${ }^{b}$ Addition of $\mathrm{H}_{2} \mathrm{SO}_{4} 10 \mu \mathrm{L} / \mathrm{g}$ of dried yeast.

\subsection{Influence of acid shock and temperature on yeast extract and protein yields}

Table 5 presents the Experimental matrix for I-Optimal design as well as the responses for total solids and proteins content in yeast extract. Generally, when the ratio between the maximum value and the minimum 
value is greater than 10, a transformation of the response data is necessary for better adjustments of the model, which is not the case.

Table 5. Experimental matrix for I-Optimal design as well as the responses for total solids and proteins content in yeast extract.

\begin{tabular}{|c|c|c|c|c|c|c|}
\hline \multirow{2}{*}{ Run } & \multicolumn{2}{|c|}{$\begin{array}{c}\text { Variables in coded } \\
\text { units }\end{array}$} & \multicolumn{2}{|c|}{$\begin{array}{c}\text { Variables in original } \\
\text { units }\end{array}$} & \multicolumn{2}{|c|}{ Responses } \\
\hline & $\begin{array}{l}\mathrm{X}_{1} \text { Temp. } \\
\left({ }^{\circ} \mathrm{C}\right)\end{array}$ & $\begin{array}{c}\mathrm{X}_{2} \text { Final } \\
\text { pH }\end{array}$ & $\begin{array}{l}\mathrm{X}_{1} \text { Temp. } \\
\left({ }^{\circ} \mathrm{C}\right)\end{array}$ & $\begin{array}{c}\mathrm{X}_{2} \text { Final } \\
\text { pH }\end{array}$ & $\begin{array}{c}\% \text { of total solids in yeast } \\
\text { extract }\end{array}$ & $\begin{array}{c}\% \text { of protein content in } \\
\text { yeast extract }\end{array}$ \\
\hline 1 & -1.0 & 0.37 & 50 & 4.54 & 17.30 & 25.62 \\
\hline 2 & -1.0 & -0.77 & 50 & 2.1 & 10.35 & 14.07 \\
\hline 3 & -1.0 & -1.00 & 50 & 1.6 & 10.03 & 11.98 \\
\hline 4 & -1.0 & 0.37 & 50 & 4.54 & 17.51 & 24.55 \\
\hline 5 & -1.0 & 1.00 & 50 & 5.9 & 7.21 & 12.14 \\
\hline 6 & -1.0 & 1.00 & 50 & 5.9 & 7.10 & 11.12 \\
\hline 7 & -0.5 & 1.00 & 60 & 5.9 & 14.78 & 24.20 \\
\hline 8 & -0.5 & -1.00 & 60 & 1.6 & 13.38 & 15.40 \\
\hline 9 & -0.5 & 0.37 & 60 & 4.54 & 20.00 & 30.43 \\
\hline 10 & -0.5 & -0.44 & 60 & 2.8 & 15.47 & 21.57 \\
\hline 11 & -0.5 & -0.44 & 60 & 2.8 & 15.47 & 21.57 \\
\hline 12 & -0.5 & -0.77 & 60 & 2.1 & 12.70 & 16.75 \\
\hline 13 & -0.5 & 1.00 & 60 & 5.9 & 14.15 & 24.74 \\
\hline 14 & 0.0 & 1.00 & 70 & 5.9 & 15.19 & 24.79 \\
\hline 15 & 0.5 & -1.00 & 80 & 1.6 & 17.28 & 20.27 \\
\hline 16 & 0.5 & 0.37 & 80 & 4.54 & 14.35 & 21.84 \\
\hline 17 & 0.5 & 1.00 & 80 & 5.9 & 14.55 & 22.91 \\
\hline 18 & 0.5 & -0.77 & 80 & 2.1 & 12.11 & 15.82 \\
\hline 19 & 0.5 & -0.44 & 80 & 2.8 & 11.45 & 17.16 \\
\hline 20 & 1.0 & -1.00 & 100 & 1.6 & 22.56 & 27.47 \\
\hline 21 & 1.0 & -0.77 & 100 & 2.1 & 14.65 & 22.10 \\
\hline 22 & 1.0 & 1.00 & 100 & 5.9 & 14.16 & 23.51 \\
\hline 23 & 1.0 & 1.00 & 100 & 4.54 & 13.31 & 22.87 \\
\hline
\end{tabular}

Table 6 presents a summary of the transformations used, the adjusted model that best suited each answer, as well as the $\mathrm{R}^{2}$ statistical data and precision analysis of the modified models, which considers only the significant terms. The final equations in terms of the real factors only for the significant terms of each modified model are also presented (Equations 1 and 2).

$$
\begin{aligned}
& \text { Protein content in yeast extract }(\%)=-59.0200+3.2209 X_{1}-32.3727 X_{2}-0.3299 X_{1} X_{2}-0.0215 X_{1}^{2}+22.5004 X_{2}^{2}- \\
& 0.0119 X_{1}^{2} X_{2}+0.2756 X_{1} X_{2}^{2}+0.0001 X_{1}^{3}-6.0385 X_{2}^{3}-0.0008 X_{1}^{2} X_{2}^{2}+0.0001 X_{1}^{3} X_{2}-0.0080 X_{1} X_{2}^{3}+0.4033 X_{2}^{4} \\
& \text { Total solids in yeast extract }(\%)=-56.9585+1.4523 X_{1}-16.4889 X_{2}+1.4355 X_{1} X_{2}-0.0004 X_{1}^{2}- \\
& 3.5046 X_{2}^{2}-0.0337 X_{1}^{2} X_{2}+0.2333 X_{1} X_{2}^{2}-0.0001 X_{1}^{3}-0.7175 X_{2}^{3}-0.0010 X_{1}^{2} X_{2}^{2}+0.0002 X_{1}^{3} X_{2}
\end{aligned}
$$

Table 6. Statistical data of the models obtained for $\%$ of protein and total solids content in yeast extract.

\begin{tabular}{ccccccc}
\hline Response & Transformation & Adjusted model & $\mathbf{R}^{2}$ & Precision & F - Value & $p$-value \\
\hline$\%$ of protein & None & quartic & 0.9960 & 60.86 & 207.97 & $<0.0001^{*}$ \\
\hline$\%$ of total solids & None & quartic & 0.9859 & 34.46 & 101.30 & $<0.0001^{*}$ \\
\hline$* p$-values less than 0.0500 indicate model terms are significant & & & & & &
\end{tabular}

The precision analysis presented in Table 6 measures the signal-to-noise ratio, i.e., it compares the range of values predicted at the design points with the average forecast error. Ratios greater than 4 are desired and indicates adequate accuracy of the model. Therefore, the equations found can be used 
to navigate the design space of all optimization experiments. $P$-values less than 0.0500 indicates that the terms of the model are significant. In this case, the equation in terms of real factors can be used to make predictions about the response for certain levels of each factor. As noted, components $\mathrm{X}_{2}{ }^{2}$ $\left(\mathrm{pH}^{2}\right)$ and $\mathrm{X}_{2}(\mathrm{pH})$ have the greatest impact on the yield of protein and total solids in yeast extract respectively. A high interaction between final $\mathrm{pH}$ and temperature was observed according to the elliptical profile observed in the contour graphs, Figure $2 \mathrm{a}, \mathrm{b}$. The best result for total solids and protein extraction were achieved with final $\mathrm{pH} 4.54$ at $60{ }^{\circ} \mathrm{C}$. Under this condition, the acid treatment showed increases of $24.37 \%$ for total solids and $35.65 \%$ for protein extraction when compared to the control group. The validation of the studied models was performed at $59{ }^{\circ} \mathrm{C}$ and $\mathrm{pH} 4.4$ as suggested by the program. The verification showed that the model presents an adequate adjustment regarding the extraction of protein and total solids that are within the confidence interval. Table 7 presents the results of the validation of the models obtained by the program.
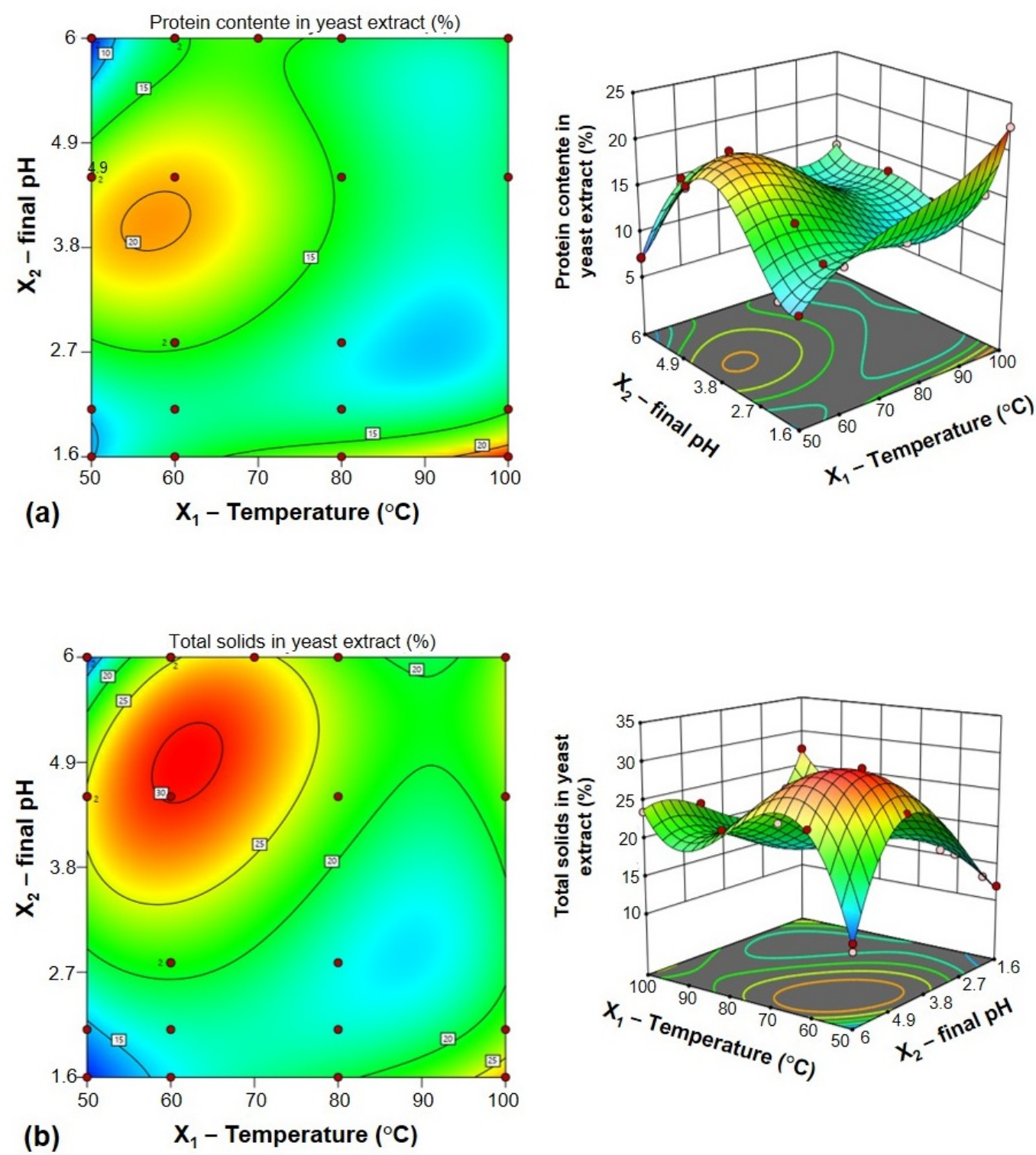

Figure 2. The response surface graphs of the temperature and final $\mathrm{pH}$ for autolysis optimization regarding the extraction of protein (a) and total solids. 
Table 7. Validation of the models obtained through the experimental design.

\begin{tabular}{cccccc}
\hline Response & Predicted Mean & Standard deviation & $\begin{array}{c}\mathbf{- 9 5 ,} \\
\text { \% Pred. }\end{array}$ & $\begin{array}{c}\mathbf{+ 9 5 ,} \\
\text { \% Pred. }\end{array}$ & Experimental value \\
\hline \% of protein & 22.5826 & 0.3558 & 21.8259 & 23.3394 & 20.1167 \\
\hline \% of total solids & 27.3094 & 0.8160 & 25.7631 & 28.8558 & 29.5833 \\
\hline
\end{tabular}

\subsection{Influence of time and temperature}

Figures $3 \mathrm{a}, \mathrm{b}$ show the values of proteins and total solids released in the treatments performed under different conditions according to Table 3 . It is observed that at the temperature of $45^{\circ} \mathrm{C}$ the control obtained better results than in autolysis with acid shock after near $12 \mathrm{~h}$. However, the experiments performed at the temperature of $60^{\circ} \mathrm{C}$ showed to be much higher in relation to the control at the same temperature in relation to the extraction of proteins and total solids. The best yields of proteins and total solids were observed for autolysis treated with acid shock and gradual increase of temperature. SDS-PAGE analysis showed that the most proteins were digested to small peptides with size range lower than $14 \mathrm{kDa}$ after $12 \mathrm{~h}$, except for the treatment at $45^{\circ} \mathrm{C}$ without acid shock (Figure 3c). Therefore, the acid shock can be correlated to a greater degradation of proteins at this temperature.

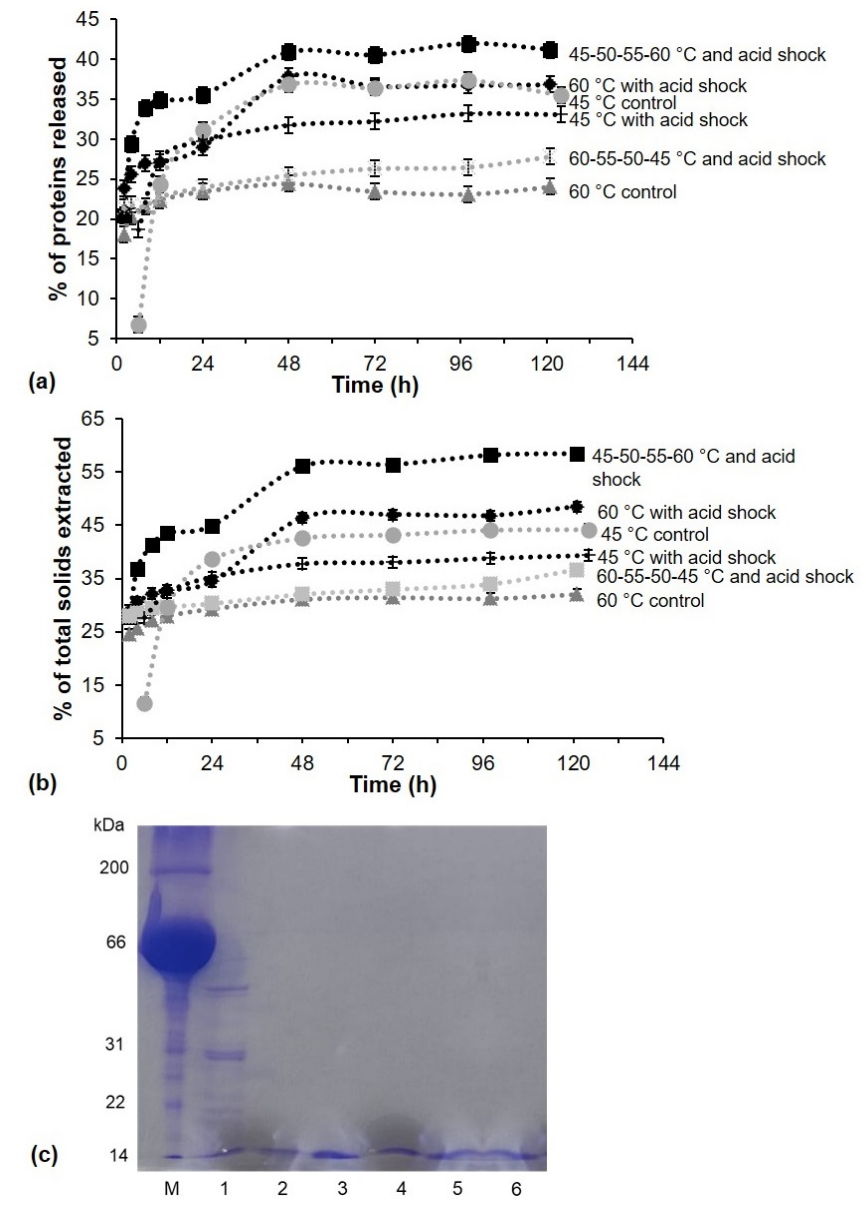

Figure 3. Percentage of proteins (a) and total solids (b) extracted in relation to the yeast dry mass during autolysis under different conditions. In control experiments there was no addition of acid. The sulfuric acid was added at a concentration of 10 $\mu \mathrm{L} / \mathrm{g}$ of dried yeast in acid shock treatments (initial $\mathrm{pH} 2.1$ and final $\mathrm{pH} 4.4$ ). Analysis of hydrolyzed protein contents after $12 \mathrm{~h}$ autolysis using $12.5 \%$ SDS-PAGE (c), $45^{\circ} \mathrm{C}$ control (1), $60{ }^{\circ} \mathrm{C}$ control (2), $45^{\circ} \mathrm{C}$ with acid shock (3), $60{ }^{\circ} \mathrm{C}$ with acid shock (4), 45-50-55-60 ${ }^{\circ} \mathrm{C}$ and acid shock (5), 60-55-50-45 ${ }^{\circ} \mathrm{C}$ and acid shock (6), protein standard marker (M). 
At low $\mathrm{pH}$ the thermotolerance mechanism of $S$. cerevisiae is inhibited and in addition, it still affects the activity of enzymes responsible for autolysis, which reach the ideal $\mathrm{pH}$ for the reaction. This explains how $\mathrm{pH}$ associated with extreme temperature are factors that accelerate yeast autolysis. The results obtained here are according to Oliveira and Gómez (2005) and Oliveira and Oliva Neto, (2011) regarding pH, which obtained better results at a $\mathrm{pH}$ in the range of 3.8 to 5 , varying a little in the temperature only, since they obtained better results in temperature of $48^{\circ} \mathrm{C}$ to $55^{\circ} \mathrm{C}$.

The biochemical mechanism that leads to the rupture of the yeast cell wall is related to the synergistic action of endogenous enzymes (glucanases, mannases and chitinases) of the cell itself (Charpentier et al., 1986). The effect of temperature on yeast cells is quite complex and affects the synthesis and activity of these enzymes, as well as cell control, transfer of anabolic information from genes to ribosomes, absorption of ions and molecules, and membrane integrity (Reed and Nagodawithana, 1990). Yeast autolysis is characterized by the degradation of cellular proteins, nucleic acids, lipids and polysaccharides, leading to cell death and solubilization of cellular biomass. This process causes cell death, but should not inactivate the responsible enzymes such as proteases, lipases and nucleases considered necessary for the autolytic process (Hernawan and Fleet, 1995). Four of the important proteolytic enzymes that play a role during lysis are: protease A; protease B; carboxypeptidase Y; and carboxypeptidase S (Reed and Nagodawithana, 1990).

Among the enzymes that participate in this process in yeast, protease A has a crucial function, being responsible for $80 \%$ of the nitrogen released during autolysis under optimal conditions (Alexandre, 2011; Charpentier et al., 1986). According to data from Maddox and Hough (1970), this protein has optimum $\mathrm{pH}$ between 2 to 6 and optimal temperature of $35^{\circ} \mathrm{C}$ to $40{ }^{\circ} \mathrm{C}$. Protease $\mathrm{B}$ has an optimum pH of 6 to 10 and optimum temperature of $45{ }^{\circ} \mathrm{C}$ to $55^{\circ} \mathrm{C}$, carboxypeptidase $\mathrm{Y}$ has its best conditions at $\mathrm{pH} 4$ to 7 and temperature of $45^{\circ} \mathrm{C}$ to $55^{\circ} \mathrm{C}$, whereas carboxypeptidase $\mathrm{S}$ the $\mathrm{pH}$ is 7 and the temperature of $60^{\circ} \mathrm{C}$. These data justify the increase of the level of extracted proteins and total solids with the gradual increase of the temperatures in the obtained results. However, when dealing with $\mathrm{pH}$ only some proteases had their optimal conditions reached, such as proteinase A and carboxypeptidase $\mathrm{Y}$.

The experiment with the gradual decrease of temperature presented results close to those found for the control autolysis at $60{ }^{\circ} \mathrm{C}$. The results obtained from acid autolysis at $60^{\circ} \mathrm{C}$ and gradual temperature increase showed the highest percentages of proteins (36.84\% and $41.20 \%)$ and solids $(48.47 \%$ and $58.48 \%)$ extracted at the end of the experiment $(121 \mathrm{~h})$.

These results demonstrate some disparities in relation to the percentage of proteins found by Tanguler and Erten (2008). When evaluating temperatures separately, after $8 \mathrm{~h}$ of incubation, they obtained a percentage of approximately $40 \%$ of proteins at $45{ }^{\circ} \mathrm{C}$ and $30 \%$ at $60{ }^{\circ} \mathrm{C}$, whereas in the present study the percentage was obtained below $30 \%$ at $45{ }^{\circ} \mathrm{C}$ and greater than $30 \%$ at $60{ }^{\circ} \mathrm{C}$ in autolysis with acid shock treatment. Likewise, significant differences were observed when compared to studies of autolysis in brewer's yeast performed by Bayarjargal et al. (2014). At temperatures of 45 and $50{ }^{\circ} \mathrm{C}$, the percentage of solids extracted was less than $15 \%$ after $30 \mathrm{~h}$ of incubation, whereas in the present study, acid autolysis at $45{ }^{\circ} \mathrm{C}$ already showed higher values in the first $2 \mathrm{~h}$.

The influence of temperature on the extraction of proteins and solids with significant increase in the first $24 \mathrm{~h}$ and subsequent stability in the following hours, observed in this study for the temperature of $45^{\circ} \mathrm{C}$, was observed by Tanguler and Erten (2008) and Liu et al. (2008) when evaluating yeast autolysis and by Bayarjargal et al. (2014) and Chae et al. (2001) when evaluating the enzymatic hydrolysis of the same microorganisms at the same temperature. However, even with the same pattern for other temperatures in these studies, in acidic autolysis with a gradual increase in temperature and $60{ }^{\circ} \mathrm{C}$ it is possible to observe another significant increase in the extraction of solids and proteins between 24 and $48 \mathrm{~h}$ until the process in fact stabilizes, with little variation, until the end of the incubation period.

The autolysate may have a variable composition and, therefore, these differences may not only be related to the process of autolysis itself, but especially to the species of yeast to be autolyzed. Podpora et al. (2015) 
attributes the difference to the fact that brewer's yeast is obtained from a suspension of the brewer's must, rich in protein, peptides and amino acids from barley malt (which may be variable) and from other additives present in the beverage production process. Another determinant factor may be related to the conditions of autolysis, since some yeast proteases have optimal temperature and $\mathrm{pH}$ to perform their proteolytic functions (Takalloo et al., 2020). Thus, the more positive results found with acid autolysis and gradual increase in temperature demonstrate that there may be a relationship with the optimal ranges of these parameters for the action of each of the enzymes in the process of autolysis.

\subsection{Evaluation of Salmonella typhimurium growth in yeast autolysate}

The growth of S. typhimurium was verified in the samples of autolysis control group after $12 \mathrm{~h}$, however in the group with acid shock autolysis the growth was observed only after $48 \mathrm{~h}$. Therefore, the acid shock was efficient to prevent growth during the most part of autolysis. According to Keerthirathne et al. (2016), Salmonella can grow in environments with temperatures between $25^{\circ} \mathrm{C}$ and $40^{\circ} \mathrm{C}$ and pH ranging from 4.5 to 9.3 , with an optimum growth temperature between $35^{\circ} \mathrm{C}$ and $37^{\circ} \mathrm{C}$ and an optimum pH between 6.5 and 7.5. Furthermore, a study conducted by Alali et al. (2012) shows that reducing the $\mathrm{pH}$ of the medium decreases the Salmonella survival rate, which corroborates the results observed here. Probably the shock acid treatment with $\mathrm{H}_{2} \mathrm{SO}_{4} 10 \mu \mathrm{L} / \mathrm{g}$ of dried yeast (corresponding to initial $\mathrm{pH} 2.1$ and final $\mathrm{pH} 4.4$ ), was enough to destroy the hydrogen pump of the bacteria, decreasing its maintenance energy. The reasons why acids are effective at preventing bacterial growth is because even for strong acids which are highly ionized, some molecules may cross the inner membrane in the nonionized form and subsequently dissociate in the periplasm (Gutknecht and Walter, 1981). According to Foster (2004), protons may also enter the cytoplasm through protein channels, transient water chains or damaged membranes. When acid stress is severe, the internal $\mathrm{pH}$ of the cell falls to levels which are too low to correct by buffering or ionic flux leading to many potential problems like lowered enzyme activity, acid-induced protein unfolding, membrane damage and DNA damage which leads to a very low cell survival under these conditions (Lund et al., 2014).

Finally, a valid advantage of the findings of this work were substantial reduction in the time of autolysis and the reduction of the risk of contamination of the process by microorganisms, considering that the majority of pathogenic bacteria cannot resist very low pHs, such as the genus Clostridium and Salmonella, which need $\mathrm{pH}$ in a range from 4.1 to 9.0. In this process, the acid shock at the beginning of the process, lower the initial $\mathrm{pH}$ to around 2.1, which leads to a reduction or retardation or total or partial inhibition of the growth of pathogenic bacteria.

\section{Conclusion}

The present study reached satisfactory and positive results in which it was able to demonstrate how time and temperature can be controlled to generate a significant improvement in efficiency in autolysate production. In addition, it could be highlighted the following advantages:

- Reduction of the reaction time, which is normally from 20 to $40 \mathrm{~h}$ in the industry, to about 6 to $12 \mathrm{~h}$. This reduction in time makes the process more productive, as it increases the production capacity with the equipment already installed, in addition to reducing energy costs related to maintaining high temperatures for several hours or days during the process.

Acidification showed to be effective as an inducer of the complex enzyme system responsible for yeast autolysis, accelerating the cell's protease and carbohydrate activation sequence. The shock increased the speed of the process since the control reached about $30 \%$ of extract at $60{ }^{\circ} \mathrm{C}$ and the same experiment, however with acid shock reached more than $43 \%$ in $12 \mathrm{~h}$. When considering the time in an industrial scale, it could be noted that the time was very important for the productivity as well as avoiding risk of pathogen contamination in autolysis, these results were very relevant for industrial purposes in the production of yeast 
extract, autolyzed yeast and glucan and mannan. Finally, the process had the potential to obtain inputs such as yeast extract, yeast autolysate, cell wall, mannooligosaccharides, invertases, RNA, 5'-ribonucleotides, vitamins and minerals, amino acids, $\beta$-glucan and proteins. All of these products came from yeast hydrolysis or cell disruption as a precursor process for other extraction and purification steps. Development of studies in this area are very important because such products are commercialized in the sectors of animal feed, medicines, human nutrition, beverages, production of culture medium, flavorings and other inputs for the food industry.

\section{Acknowledgements}

The authors gratefully acknowledge São Paulo Research Foundation (Fundação de Amparo à Pesquisa do Estado de São Paulo (FAPESP)) for Ph.D. Scholarship (grant 2016/08886-6).

\section{References}

Alali, W. Q., Mann, D. A., \& Beuchat, L. R. (2012). Viability of Salmonella and Listeria monocytogenes in delicatessen salads and hummus as affected by sodium content and storage temperature. Journal of Food Protection, 75(6), 1043-1056. PMid:22691471. http://dx.doi.org/10.4315/0362-028X.JFP-11-505

Alexandre, H. (2011). Downstream processing and product recovery - autolysis of yeasts. In M. Moo-Young (Ed.), Comprehensive Biotechnology (2nd ed., pp. 641-648.). Oxford: Pergamon Press.

Association of Official Agricultural Chemists - AOAC. (2000). Official methods of analysis (17th ed.). Gaithersburg: Horwitz W. Baird, R. B., Eaton, A. D., \& Rice, E. W. (2017). Standard methods for the examination of water and wastewater (23nd ed.). Washington, DC: APHA.

Bataeva, D. S., Makhova, A. A., Krylova, V. B., Gustova, T. V., \& Minaev, M. Y. (2020). Clostridium spp. detection in food samples using 16S rDNA-based PCR method. In E. P. Tomasini IOP Conference Series: Earth and Environmental Science (pp. 052025). Bristol: IOP Publishing. http://dx.doi.org/10.1088/1755-1315/421/5/052025.

Bayarjargal, M., Munkhbat, E., Ariunsaikhan, T., Odonchimeg, M., Uurzaikh, T., Gan-Erdene, T., \& Regdel, D. (2014). Utilization of spent brewer's yeast Saccharomyces cerevisiae for the production of yeast enzymatic hydrolysate. Mongolian Journal of Chemistry, 12, 88-91. http://dx.doi.org/10.5564/mjc.v12i0.179

Biospringer. (2021). Yeast extract is an ingredient on the rise. Retrieved in 2021, January 13, from https://biospringer.com/en/yeast-extract-an-ingredient-on-the-rise/

Chae, H. J., Joo, H., \& In, M. J. (2001). Utilization of brewer's yeast cells for the production of food-grade yeast extract. Part 1 : effects of different enzymatic treatments on solid and protein recovery and flavor characteristics. Bioresource Technology, 76(3), 253-258. PMid:11198178. http://dx.doi.org/10.1016/S0960-8524(00)00102-4

Charpentier, C., Van Long, T. N., Bonaly, R., \& Feuillat, M. (1986). Alteration of cell wall structure in Saccharomyces cerevisiae and Saccharomyces bayanus during autolysis. Applied Microbiology and Biotechnology, 24(5), 405-413. http://dx.doi.org/10.1007/BF00294598

Foster, J. W. (2004). Escherichia coli acid resistance: Tales of an amateur acidophile. Nature Reviews. Microbiology, 2(11), 898-907. PMid:15494746. http://dx.doi.org/10.1038/nrmicro1021

Ghoush, A. L., \& Khatib, E. S. (2021). Yeast extract: A potential substitute of salt in baked crackers. International Journal of Environment, Agricultural Biotechnology, 6(1), 86-94.

Gutknecht, J., \& Walter, A. (1981). Transport of protons and hydrochloric acid through lipid bilayer membranes. Biochimica et Biophysica Acta 641(1), 183-188. PMid:6260181. http://dx.doi.org/10.1016/0005-2736(81)90582-4

Hernawan, T., \& Fleet, G. (1995). Chemical and cytological changes during the autolysis of yeasts. Journal of Industrial Microbiology, 14(6), 440-450. PMid:7662285. http://dx.doi.org/10.1007/BF01573955

Jo, M. N., \& Lee, Y. M. (2008). Analyzing the sensory characteristics and taste-sensor ions of MSG substitutes. Journal of Food Science, 73(5), S191-S198. PMid:18577010. http://dx.doi.org/10.1111/j.1750-3841.2008.00769.x

Keerthirathne, T. P., Ross, K., Fallowfield, H., \& Whiley, H. (2016). A review of temperature, pH, and other factors that influence the survival of Salmonella in mayonnaise and other raw egg products. Pathogens, 5(4), 63. PMid:27869756. http://dx.doi.org/10.3390/pathogens5040063

Kellershohn, J., \& Russell, I. (2016). Yeast biotechnology. In R. V. Ravishankar (Ed.), Advances in food biotechnology (pp. 303310). Hoboken: John Wiley \& Sons Ltd. http://dx.doi.org/10.1002/9781118864463.ch18.

Laemmli, U. K. (1970). Cleavage of structural proteins during the assembly of the head of bacteriophage T4. Nature, 227(5259), 680-685. PMid:5432063. http://dx.doi.org/10.1038/227680a0

Liu, X. Y., Wang, Q., Cui, S. W., \& Liu, H. Z. (2008). A new isolation method of $\beta$-D-glucans from spent yeast Saccharomyces cerevisiae. Food Hydrocolloids, 22(2), 239-247. http://dx.doi.org/10.1016/j.foodhyd.2006.11.008 
Lund, P., Tramonti, A., \& Biase, D. (2014). Coping with low pH: Molecular strategies in neutralophilic bacteria. FEMS Microbiology Reviews, 38(6), 1091-1125. PMid:24898062. http://dx.doi.org/10.1111/1574-6976.12076

Macedo, J. V. C., Ranke, F. F. B., Escaramboni, B., Campioni, T. S., Núñez, E. G. F., \& Oliva Neto, P. (2020). Cost-effective lactic acid production by fermentation of agro-industrial residues. Biocatalysis and Agricultural Biotechnology, 27, 101706. http://dx.doi.org/10.1016/j.bcab.2020.101706

Maddox, I. S., \& Hough, J. S. (1970). Proteolytic enzymes of Saccharomyces carlsbergensis. The Biochemical Journal, 117(5), 843-852. PMid:5451908. http://dx.doi.org/10.1042/bj1170843

Malekkhahi, M., Tahmasbi, A. M., Naserian, A. A., Danesh-Mesgaran, M., Kleen, J. L., AlZahal, O., \& Ghaffari, M. H. (2016). Effects of supplementation of active dried yeast and malate during sub-acute ruminal acidosis on rumen fermentation, microbial population, selected blood metabolites, and milk production in dairy cows. Animal Feed Science and Technology, 213, 29-43. http://dx.doi.org/10.1016/j.anifeedsci.2015.12.018

Musicus, A. A., Kraak, V. I., \& Bleich, S. N. (2020). Policy progress in reducing sodium in the american diet, 2010-2019. Annual Review of Nutrition, 40(1), 407-435. PMid:32966183. http://dx.doi.org/10.1146/annurev-nutr-122319-040249

Oliveira, A. M., \& Gómez, R. J. C. (2005). Otimização da extração de proteínas de levedura Saccharomyces cerevisiae. SEMINA, 26(4), 521-534.

Oliveira, A. M., \& Oliva Neto, P. D. (2011). Improvement in RNA extraction from S. cerevisie by optimization in the autolysis and NH3 hydrolysis. Brazilian Archives of Biology and Technology, 54(5), 1007-1018. http://dx.doi.org/10.1590/S151689132011000500019

Podpora, B., Swiderski, F., Sadowska, A., Piotrowska, A., \& Rakowska, R. (2015). Spent brewer's yeast autolysates as a new and valuable component of functional food and dietary supplements. Journal of Food Processing \& Technology, 6(12), 1000526.

Pozo-Bayón, M. A., Andujar-Ortiz, I., Alcaide-Hidalgo, J. M., Martín-Álvarez, P. J., \& Moreno-Arribas, M. V. (2009). Characterization of commercial inactive dry yeast preparations for enological use based on their ability to release soluble compounds and their behavior toward aroma compounds in model wines. Journal of Agricultural and Food Chemistry, 57(22), 10784-10792. PMid:19856918. http://dx.doi.org/10.1021/jf900904x

Reed, G., \& Nagodawithana, T. W. (1990). Yeast-derived products. In G. Reed \& T. W. Nagodawithana (Eds.), Yeast technology (pp. 369-412). Dordrecht: Springer. http://dx.doi.org/10.1007/978-94-011-9771-7_9.

Šuklje, K., Antalick, G., Buica, A., Coetzee, Z. A., Brand, J., Schmidtke, L. M., \& Vivier, M. A. (2016). Inactive dry yeast application on grapes modify Sauvignon Blanc wine aroma. Food Chemistry, 197(Pt B), 1073-1084. PMid:26675843. http://dx.doi.org/10.1016/j.foodchem.2015.11.105

Takalloo, Z., Nikkhah, M., Nemati, R., Jalilian, N., \& Sajedi, R. H. (2020). Autolysis, plasmolysis and enzymatic hydrolysis of baker's yeast (Saccharomyces cerevisiae): A comparative study. World Journal of Microbiology \& Biotechnology, 36(5), 68. PMid:32328815. http://dx.doi.org/10.1007/s11274-020-02840-3

Tanguler, H., \& Erten, H. (2008). Utilisation of spent brewer's yeast for yeast extract production by autolysis: The effect of temperature. Food and Bioproducts Processing, 86(4), 317-321. http://dx.doi.org/10.1016/j.fbp.2007.10.015

Transparency Market Research. (2021). Autolyzed Yeast Extract Market - Global Industry Analysis, size, share, growth, trends, and forecast 2018 - 2026. Retrieved in 2021, January 13, from: https://www.transparencymarketresearch.com/autolyzed-yeastextract-market.html

Funding: São Paulo Research Foundation (FAPESP), grant 2016/08886-6. 